\title{
Economic Growth and Unemployment: An Empirical Assessment of Okun's Law in The Case of Liberia (2001-2019)
}

\author{
Kaiballah Conteh* \\ E-mail: kaiballahconteh@gmail.com_Tel: +905428809680 \\ Department of Economics, Near East University \\ East Boulevard, ZIP: 99138 \\ Nicosia TRNC Mersin 10- Turkey Tel: + 90(392)2236464 \\ E-mail: info@neu.edu.tr
}

\begin{abstract}
The purpose of this study is to examine the connection between economic growth and unemployment in Liberia between 2001-2019. The unit root test and the Augmented Dickey-Fuller (ADF) Co-integration test were used to examine the relationship between unemployment and GDP. The Auto Regressive Distribution Lag (ARDL) bounds test is used to determine if the variables are linked in the long run. According to the results of the ARDL model, there is no long-run relationship between unemployment and economic growth. This study' results have particularly important policy implications for Liberian economic authorities. In both the long and medium term, the observational results show no meaningful relationship between unemployment and economic growth. The Liberian government should direct its spending toward activities that directly and indirectly promote the creation of employment and decent jobs, a conducive environment and flexible labor market policies or legislations that are not impediments to job creation, and finally, the government should prioritize labor intensive industries.
\end{abstract}

Keywords: Okun's law, unemployment rate, Economic Growth, Liberia

DOI: $10.7176 / \mathrm{JESD} / 12-14-13$

Publication date:July $31^{\text {st }} 2021$

\section{Introduction}

For many years, Liberia's unemployment rate has been reported at 85 percent, which is utterly impossible. In late 1991 and early 1992, this figure was suggested as the unemployment rate. Liberia's civil war was at its peak at the time; all government offices had been shuttered, and many major businesses, including the LiberianAmerican-Swedish Mining Company (LAMCO) and Firestone, had been taken over by fighting factions. During the battle, the economy completely collapsed.

Prior to the civil war, the Liberian economy was highly reliant on iron ore mining. Liberia was a major iron ore exporter on the global market. Iron mining accounted for more than half of Liberia's export revenues by the 1970s. Since the 1980 coup, the country's economic growth rate has decreased due to a drop in global demand for iron ore and political instability in Liberia. Following a period of rapid growth in 1979, the Liberian economy began to deteriorate steadily as a result of economic mismanagement following the 1980 coup.

The start of civil conflict in 1989 exacerbated this drop; GDP fell by an estimated 90\% between 1989 and 1995 , one of the steepest decreases recorded in history. The United Nations sanctioned Liberia in 2001 for its backing for the Revolutionary United Front (RUF) rebels in neighboring Sierra Leone. Following the 2005 elections, these restrictions were lifted.

Following the conclusion of the conflict in 2003, GDP growth resumed, peaking at 9.4 percent in 2007. The global financial crisis reduced GDP growth to 4.6 percent in 2009 , but a stronger agriculture sector lead by rubber and timber exports improved growth to 5.1 percent in 2010. Liberia has relied extensively on foreign aid, notably from the United States, Sweden, the United Kingdom, France, Italy, Germany, Romania and the People's Republic of China.

Due to favorable global commodity prices, the nation saw rapid growth from 2010 to 2013. However, the economy suffered during the 2014-2015 Ebola epidemic, and many foreign-owned firms left with their cash and skills. The outbreak compelled the government to devote precious resources to battle the virus's spread, limiting money available for critical public investment. The cost of combating the Ebola outbreak corresponded with lower economic activity, which reduced government revenue, however increased donor funding more than 
compensated this loss. Global commodity prices for major exports dropped during the same period and have yet to rebound to pre-Ebola levels.

\subsection{Unemployment}

The International Labour Organization (ILO) defines the jobless as the number of economically productive people who are unemployed but qualified for and seeking work, including those who have lost their jobs and those who have voluntarily left their occupations (World Bank, 1998:63). Housewives, full-time instructors, individuals under the legal working age, and the elderly are just a few examples. The unemployment rate is computed as a percentage of the total number of individuals searching for work at any particular point in time. In economics, it is widely assumed that an economy's GDP growth rate increases employment and reduces unemployment. Population growth and unemployment remain significant problems in all countries, regardless of economic development. Countries' development plans are aimed at increasing economic prosperity and decreasing unemployment.

Despite a vast amount of research on the link between economic growth and unemployment, there is little consensus on the direction and intensity of the relationship. Differences in country economic systems have a significant effect on the connection between economic growth and unemployment. Okun's Law is a scientific hypothesis that connects productivity with unemployment. This is one of the most well-known connections in macroeconomic theory, and it has been shown to be valid for a variety of nations and continents, most notably emerging countries (Lee, 2000; Farsio and Quade, 2003; Christopoulos, 2004; Daniels and Ejara, 2009). Longterm inflation, along with job-creation measures, progressively lowers the critical problem of unemployment. Growth is required for humanity's growth and development. People's living conditions increase as a result of economic growth.

Unemployment, according to Okun (1962), as cited by Kemi and Dayo (2014), has a negative relationship with economic growth. As a result, changes in total demand affect agricultural production patterns, which in turn affect labor demand, changing a country's unemployment situation. Economists have taken note of this pattern, not just for its high methodological regularity, but also for its importance as a macroeconomic building component. When contrasted to the Phillips curve, it gives the aggregate supply curve.

It also has implications for macroeconomic policy, particularly in determining the optimal or ideal growth rate Mossa and Dahmani (2008). Because of the prevalence of underemployment, the unemployment problem in Liberia has taken on new dimensions. In this instance, some people are working but are underpaid, prohibiting them from fulfilling basic necessities such as food, clothing, and shelter. Kemi and Dayo (2014) examined a different kind of unemployment known as disguised unemployment, which happens when individuals accept jobs that are inadequate for their educational credentials and experience. The purpose of this study is to establish if Okun's law is applicable in Liberia. The study will look particularly at the impact of unemployment on Liberian economic growth and the susceptibility of productivity to changes in unemployment rates in both the short and long term. According to Osinubi (2005), although economic development is essential in decreasing unemployment and relieving poverty, it is insufficient since economic growth cannot address all of the critical variables that contribute to poverty and unemployment. As a consequence, further measures to assist in the development of investment projects that will enable job creation, promote economic growth, and relieve poverty and unemployment are required.

This study provides an analytical summary of Liberia's controversial connection between GDP and unemployment. The graphs below depict the changes in the unemployment rate and economic growth from 2001 to 2019. Liberia experienced a devastating drop in the growth rate by-30\% during the civil war in 2003 and started to recover from 2004 onward. Despite the increase in the growth rate, unemployment continued to increase instead of decreasing. 
Figure 1: GDP growth and unemployment in Liberia

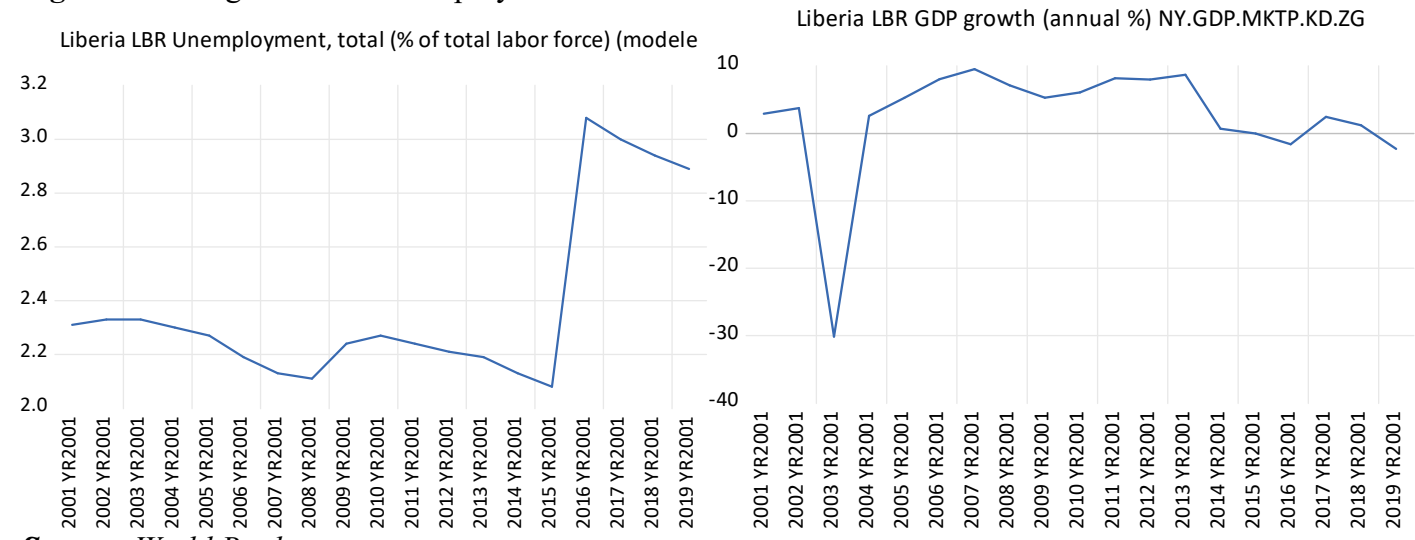

Source: World Bank

The following is the structure of this article: Section two covers a literature review, while Section three addresses evidence and techniques. Section four delves into scientific results, while Section five wraps up and offers policy suggestions.

\section{Review of Literature \\ 2.1 Unemployment and economic growth}

Several experts are curious in the relationship between unemployment and economic growth (Lee, 2000; Viren, 2001; Harris and Silverstone, 2001; Sogner and Stiassny, 2002). Okun's study empirically verified this connection. In his study of the United States based on labor force participation, hours of service, and growth evolution, Okun (1962) found an inverse relationship between the unemployment rate and potential production. Indeed, Okun (1962) showed that the theoretical basis of these investigated connections is based on the notion that an increase in labor force would result in more goods and services. Furthermore, he found that when the real growth rate was high, the unemployment rate dropped, while it increased when the real growth rate was low or even negative.

Despite much theoretical and analytical research on the connection between unemployment and economic development conducted over the past few decades, policymakers remain split on the subject. The paper offers a brief summary of the many studies that investigated the relationship between unemployment and economic growth. Arthur Okun was a pioneer in the study of the link between unemployment and economic development. According to Okun's (1962) study, when GDP grows exponentially, the unemployment rate decreases; when growth is sluggish or negative, the unemployment rate rises; and when growth approaches potential, the unemployment rate remains constant. Following that, the majority of tests were carried out to establish the validity of Okun's rule.

In Zimbabwe, Saungweme et al. (2019) investigated the connection between economic growth, formal employment, gross fixed capital formation and money supply. The independent variables were economic growth, gross fixed capital formation and money supply, whereas the dependent variable was formal employment. The Ordinary Least Squares technique was employed in the research to find that economic growth and gross capital creation had a favorable effect on formal employment. As a consequence of increasing economic development in Zimbabwe, more employments are created, while the acquisition of equipment in Zimbabwe generates more jobs and improves production capacity, resulting in formal job creation.

Knotek (2007) estimated Okun's law using three versions: difference, gap, and dynamic, in which he calculated effects on unemployment rate by current output, past output level, and past unemployment rate, and analyzed how a slowdown in the economy is not always accompanied by an increase in the unemployment rate in both the short and long run.

Mitchell and Pearce (2010) found that the unemployment rate and GDP growth move in opposing directions, but that the unemployment rate change has less impact on GDP growth than Okun's coefficient benchmark.

Moosa (1997) studied Okun's law's application to the United States and found that North America has the 
greatest coefficient and Japan has the lowest, which may be explained by differences in labor market rigidities. Sadiku et al. (2015) discovered that when using Okun's law and four types of models (difference model, dynamic model, ECM, and VAR estimation approach) on quarterly Macedonia data from 2000 to 2012, not all models have clear proof and do not support an inverse relationship between the unemployment rate and economic development, as Okun's law suggested.

Prachowny (1993) approximated Okun's law using its gap version, then computed the NAIRU and output gap, and confirmed the negative connection between the variables involved. Freeman (2001) tested Okun's law for ten industrial countries (the United States, the United Kingdom, Japan, Canada, Germany, Italy, France, the Netherlands, Sweden, and Australia), including new developments with trend decomposition, and discovered that Okun's coefficient, which was originally three points for every one percent increase in GDP, is now less than two points.

Christopoulos (2004) approximated Okun's law at the regional level in Greece using unit root tests and cointegration tests on panel data and found that the findings are consistent in six of the thirteen areas examined. Okun's law was derived for the Austrian economy by Sogner (2001) using quarterly unemployment and GDP growth data. Okun's coefficient was found to be 4.16, which was once estimated to be 2 to 3 percent. Okun's coefficients are lower in industrialized nations with less controlled labor markets, according to Neely (2010). Unemployment is more sensitive to fluctuations in production since it is simpler to lay off employees. "The Okun's coefficient may vary," he adds.

Other studies have examined economic growth and unemployment using a broader range of factors (for example, Alrayes and Wadi 2018; Bayar 2016; Sahoo and Sahoo 2019; Sahnoun and Abdennadher 2019; Ramudo et al. 2014). Alrayes and Wadi (2018) examined the variables that lead to Bahrain's unemployment. Economic growth, inflation, government expenditure, and gross capital creation were all examined in the study. After doing a time series study, the authors found that economic growth and inflation had little impact on unemployment. The research, on the other hand, found a positive connection between gross capital creation, government expenditure, and unemployment. In a research performed in India between 1991 and 2017, Sahoo and Sahoo (2019) utilized the same technique and variables. Economic growth and gross capital creation, according to the study's results, are positively linked to unemployment.

Economic growth increase and decrease have little impact on unemployment in Bahrain. Increased economic development in India, on the other hand, is accompanied with a rise in the unemployment rate. Because of the economic strategies adopted in each nation, the results vary.

Villaverde and Maza (2009) investigated Okun's rule in the Spanish provinces between 1980 and 2004. In the majority of areas and throughout the world, they found an inverse relationship between unemployment and economic development. As a consequence, they hypothesized that there is a regional variation in efficiency, which explains the coefficient heterogeneity.

Michael et al. (2016) investigated the relationship between long-term economic growth and unemployment in Nigeria from 1980 to 2013 using the cointegration test, the Vector Error Correction Model (VECM) method, and the Granger causality test. The study found a comparable connection between unemployment and economic growth factors, that unemployment has a negative and significant impact on GDP, and that there is a unidirectional relationship between unemployment and GDP, with causation extending from economic growth to unemployment.

Geidenhuys and Marinkov (2007) tried to address the issue of how South African unemployment reacts to changes in production. As a consequence, the connection between economic activity and the unemployment rate was determined. From 1970 to 2005, the results showed the existence of an Okun's law connection in South Africa, with greater evidence pointing to asymmetries during recessions. From 1994 to 2012, Banda (2016) investigated the relationship between unemployment and economic development in South Africa. The findings of Johansen co-integration revealed that the variables were related in the long term. The results show a positive relationship between GDP and unemployment in South Africa.

Biyase and Bonga-Bonga (2010) utilized OLS to establish that the connection between growth and jobs is 'paradoxical,' implying that the South African unemployment rate is ascribed to export output that is insufficiently job-generating, despite rising labor force participation rates. 
Kreishan (2011) used time series analysis methods such as the co-integration test and the Durban Watson (CRDW) approach to examine this connection on the Jordanian economy from 1970 to 2008 . He found that Okun's rule is unreliable for Jordan since Jordan's unemployment issue is not explained by a lack of development.

Furthermore, Al-Eid and Bahadi (2012) investigated the likelihood of the existence of this collaboration in the Palestinian territories from 1996 to 2011 using a simple regression model on yearly data. The experimental results revealed a poor reciprocal relationship between GDP development and the unemployment rate, with a one-unit increase in GDP resulting in a 0.25 percent decrease in the annual growth rate of unemployment in the Palestinian territories overall, 2.05 percent in the West Bank, and 0.31 percent in Gaza.

Amassoma and Nwosa (2013) investigated the relationship between Nigeria's unemployment rate and productivity development between 1986 and 2010 using the Johansen co-integration test and the error correction model (ECM) technique. The stationarity test was carried out using the Augmented Dickey-Fuller (ADF) and Phillips-Perron unit root analyses, and the results showed that both variables were integrated in the same order at first difference. The results of the Johansen co-integration test revealed that the variables under investigation had a long run equilibrium connection. Keller and Nabil (2002) discovered that MENA nations' economic growth was inadequate in contrast to the region's labor force, and that strong growth does not ensure favorable labor market results.

While Juda and Esa (2010) attempted to estimate the Okun coefficient in Iraq in the short and long term, the analysis results revealed that the unemployment rate is insensitive to changes in GDP, and the correlation coefficient between the two variables is weaker due to Iraq's employment policy, and thus it is incompatible with its economic policies. As a consequence, this legislation falls short of Iraq's needs.

Okun's law was tested for ten industrial countries (the United States, the United Kingdom, Japan, Canada, Germany, Italy, France, the Netherlands, Sweden, and Australia), including new developments with trend decomposition, and Freeman (2001) discovered that Okun's coefficient, which was originally three points, is now only less than two points of GDP growth for every one percent change in unemployment.

Al-Ghannam (2003) examined the connection between the rate of economic growth and employment in Saudi private businesses using the co-integration test and error correction model. According to Granger, causation resulted in the presence of a long-term balancing connection between the employment rate and economic growth, as well as the existence of a causal link only in one direction, from economic growth rate to employment, rather than vice versa. This connection was also studied by Al-Habees and Abu Rumman (2012) in the Jordanian and Arab economies. They found a highly good pattern of high growth rates and a relative reduction in unemployment, but this does not indicate the presence of a significant connection.

Irfan et al. (2010) examined the validity of Okun's rule in various Asian nations using yearly data from 1980 to 2006. Okun's Law does not applicable in certain Asian emerging nations, they found. Using micro-econometric evidence and fixed-effect regression techniques, Zagler (2006) showed a substantial and negative connection between unemployment and economic growth in the United Kingdom. Furthermore, using Nigerian data from 2000 to 2008, Oye and Inuwa (2011) demonstrated that unemployment has a significant (over 65 percent) effect on Nigerian GDP realization, that unemployment and GDP have an inverse relationship, and that any increase in unemployment leads to a decrease in GDP and vice versa.

Ritsakis and Stamatiou (2016) used yearly data from Greece from 1995 to 2015 to apply the (ARDL) and ECMARDL models. They showed that unemployment and economic growth have a unidirectional causal connection, with the relationship pointing from unemployment to economic growth.

Tiryaki and Ozkan (2011) analyzed Turkish quarterly data from 1998 to 2010 and found one-way causation spanning from the GDP gap to unemployment.

Empirical studies have been conducted to examine the relationship between unemployment and production (Lee, 2000; Viren, 2001; Silverstone and Harris, 2001; Sogner and Stiassny, 2002). These studies mainly demonstrated the validity of the relationship between output and the unemployment rate. The Okun coefficient estimates, on the other hand, vary greatly between countries and regions. Moosa (2008) investigated the legality of Okun's law in four Arab countries: Algeria, Egypt, Morocco, and Tunisia. He discovered that increased production does not lead to increased employment in the four countries, thus Okun's coefficient is statistically insignificant. 
Yousefat (2011) used the correlation matrix, casual and test, simultaneous integration technique, and error correction model to study the Algerian economy from 1970 to 2009. The findings revealed the existence of a slight and inverse causal relationship between unemployment and economic growth, as well as the absence of a long or short-term balancing relationship between unemployment and economic growth rates, while the causality test revealed the existence of a causal relationship from unemployment to growth.

In general, most research, particularly in developing nations, confirms Okun's (1962) connection to assess the relationship between the product and the unemployment rate, although the results vary by country and over time depending on the kind of economic development accomplished in each state. Revenge and Beutalia; Lee, 1995; Sogner \& Stiassny, 2000; Harris \& Silverstone, 2002; Zagler, 2001; Yerdelen, 2003; Ivan \& Oleg, 2011, u.d.

\section{The Data and Methodology}

From 2001 to 2019, the study utilized yearly statistical data collected from the global development indicators (World Bank data) on Liberia's unemployment rate and economic growth rate.

As a result, our study recorded economic growth as GDP growth (percent yearly) and unemployment as the rate of jobless labor force in relation to the labor force of the nation. As a consequence, the study would take two factors into account: unemployment and economic growth (GDP).

Table 1: Variables in descriptive statistics

\begin{tabular}{|l|l|l|}
\hline Descriptive statistics & Liberia GDP per annual & $\begin{array}{l}\text { Liberia unemployment total } \\
\text { (labor force) }\end{array}$ \\
\hline Mean & 2.419872 & 2.381053 \\
\hline Medium & 3.763018 & 2.270000 \\
\hline Maximum & 9.535280 & 3.080000 \\
\hline Minimum & -30.14513 & 2.080000 \\
\hline Std. Dev. & 8.659118 & 0.326325 \\
\hline Skewness & -2.933281 & 1.277449 \\
\hline Kurtosis & 11.82255 & 2.980702 \\
\hline & & 5.167905 \\
\hline Jarque-Bera & 88.86770 & 0.075475 \\
\hline Probability & 0.000000 & \\
\hline & & 45.24000 \\
\hline Sum & 45.97756 & 1.916779 \\
\hline Sum Sq. Dev. & 1349.646 & \\
\hline & 19 & \\
\hline Observation & & \\
\hline
\end{tabular}

Source: Author's calculation

\subsection{Specifications for the Model}

In this study, the Okun's (1962) style model was utilized, but it was modified to include unemployment as the independent variable and economic growth as the dependent variable, as measured by GDP. The Okun's Law is a shortened version of the Philips curve that implies an inverse relationship between GDP growth and unemployment.

$\mathrm{GDP}=\mathrm{f}($ Unemp.) $(1)$

Therefore, $\mathrm{RGDP}=\beta_{1}+\beta_{2}$ Unemp $+\mu$

Where GDP- denotes the rate of GDP growth (Economic Growth)

- Unemp- denotes the unemployment rate;

- $\beta_{1}, \beta_{2}$ - are the parameters

- $\mu$ - is the error term 
In order to approximate equation 1 , the stability characteristics of the variables utilized were first examined. As two-unit root tests, the Augmented Dickey-Fuller (ADF) and Philips-Perron (PP) experiments were included in the study. The selection of these metrics was driven by the imperatives of contrast and precision. The PP unit root test, according to Hamilton (1994), has better reliability than the ADF because it is more robust in the face of serial correlation and heteroscedasticity, but it has its own disadvantages. The study also used a novel estimation technique known as limits testing to test for co-integration inside an autoregressive distributive lag (ARDL) system proposed by Pesaran and colleagues (Pesaran 1997, Pesaran and Shin 1999 and Pesaran 2001). Because the order of integration is no longer relevant, the ARDL may be employed in this study regardless of whether the repressors are $\mathrm{I}(0)$ or $\mathrm{I}(1)$.

The purpose of this research is to examine a long-term connection by evaluating an error-correction model with no preset error rates. (UECM): $\Delta L Y_{t}=\alpha_{1}+\alpha T T+\alpha L Y_{t-1}+\alpha U n e m p l L U n e m p l_{t-1}+\sum \alpha i \Delta L Y_{t-i} P{ }_{\mathrm{i}=1}+\sum_{1}$ $\alpha j \Delta U N_{t-\mathrm{j}} q_{j=0}+\varepsilon_{1 t}$ (3). The ARDL approach, which begins by defining and calculating a generic distributed lag model, involves co-integration among variables as a rationale for maintaining lagged level variables in Equation 3. Two asymptotic critical value limits provide a benchmark for co-integration when the independent variables are $\mathrm{I}(\mathrm{d})$ with $0 \mathrm{~d} 1$. Both limits are based on the assumption that all repressors are $\mathrm{I}(0)$. If the measured $\mathrm{F}$ statistics are less than the lower limit critical value, the null hypothesis of no co-integration is rejected.

If the observed F-statistics is higher than the upper limit critical value when calculating the F-statistics, the null hypothesis is rejected, indicating that the variables in the model are in steady state equilibrium. The study analyzes the model's normality and homoscedasticity to validate the ARDL conclusion.

\subsection{Findings of the study or empirical results}

Table 2. Unit root test

\begin{tabular}{|l|l|l|l|l|l|l|}
\hline Variable & Test & T- statistics & P-Value & T- statistics & P-Value & $\begin{array}{l}\text { Order } \\
\text { integration }\end{array}$ \\
\hline Level & \multicolumn{5}{|l|}{} \\
\hline RGDP & ADF & -3.507009 & 0.0202 & -6.252039 & 0.0001 & $1(0)$ \\
\hline & P-P & -3.507009 & 0.0202 & -8.847041 & 0.0000 & $1(0)$ \\
\hline UNEMP & ADF & -1.945931 & 0.5898 & -4.373733 & 0.0038 & $1(1)$ \\
\hline & P-P & -1.953719 & 0.5859 & -4.464993 & 0.0032 & $1(1)$ \\
\hline
\end{tabular}

Source: Author's calculation

The variables in table 2 were submitted to the unit root test to establish stationarity at level and first difference using Phillip-Perron test statistics and the Augmented Dickey Fuller test (ADF). According to the unit root calculation, the GDP growth rate is stationary at both the level and the first difference, while the unemployment variables suffer unit root issues at $\mathrm{I}(0)$ and are made stationary at the first difference. We utilized the ARDL estimate test and the limits test on the two variables to test for short and long run dynamism since the order of the integration variables is zero and one, respectively. The tests' findings showed that there is no co-integration in both the short and long term at 5\%.

See the bound test below:

\section{F-Bounds Test}

Null Hypothesis: No levels relationship

\begin{tabular}{lcrrr}
\hline \hline Test Statistic & Value & Signif. & $\mathrm{I}(0)$ & $\mathrm{I}(1)$ \\
\hline \hline & & \multicolumn{3}{c}{ Asymptotic: $\mathrm{n}=1000$} \\
F-statistic & 2.255116 & $10 \%$ & 3.02 & 3.51 \\
$\mathrm{k}$ & 1 & $5 \%$ & 3.62 & 4.16 \\
& & $2.5 \%$ & 4.18 & 4.79 \\
& & $1 \%$ & 4.94 & 5.58
\end{tabular}

The ARDL bounds test and the approximation F-test results indicate that there is no long-run relationship between variables. At the 5\% level of significance, the decision criterium is based on the F-statistic (2.255116), which is less than the upper limit critical value of 4.16. As a consequence, we should not reject the null hypothesis that co-integration does not exist. 
Table 3. Short-Run ARDL

\begin{tabular}{|l|l|l|l|l|}
\hline Variable & Coefficient & Std. error & t-statistic & Prob.*** \\
\hline C & 97.50311 & 47.14150 & 2.068308 & 0.0934 \\
\hline UNEMP & -3.481241 & 3.660105 & -0.951132 & 0.3852 \\
\hline
\end{tabular}

Source: Author's calculation

Note: The ARDL estimate shows that there is no co-integration

Table 5 showed the estimated ARDL test's short-run connection between unemployment and economic growth. GDP was the dependent variable, while unemployment was the independent variable. According to the results, there is no connection between GDP growth and unemployment at 5\% level significance.

Table 4. Long-Run ARDL

\begin{tabular}{|l|l|l|l|l|}
\hline Variable & Coefficient & Std. error & t-statistic & Prob.*** \\
\hline C & 121.7520 & 56.55583 & 2.152775 & 0.0840 \\
\hline UNEMPL & -52.61276 & 25.50423 & -2062903 & 0.0941 \\
\hline
\end{tabular}

Source: Author's calculation

The ARDL estimate showed that there is no co-integration at the level of $5 \%$ significance

The unemployment rate has an insignificant effect on Liberia's export development, according to the long-term co-integration prediction in table 4 . This is shown by the country's increasing trend in both unemployment and real GDP growth. The likelihood of unemployment is more than 0.05 percent, according to the results. The conclusion is that the unemployment situation has no effect on the economy's productive performance.

Table 5: Residual Diagnostic tests

\begin{tabular}{|l|l|l|l|}
\hline Test & Null Hypothesis & Statistic value & Probability \\
\hline $\begin{array}{l}\text { Breush-Godfrey Serial } \\
\text { correlation (LM) test }\end{array}$ & $\begin{array}{l}\text { No serial correlation at up to } \\
\text { 2 lags }\end{array}$ & 0.058021 & 0.9438 \\
\hline Jarque-Bera (JB) & $\begin{array}{l}\text { Residuals are normally } \\
\text { distributed }\end{array}$ & 122.5921 & 0.000000 \\
\hline White (CH-sq) & $\begin{array}{l}\text { No conditional } \\
\text { heteroskedasticity }\end{array}$ & 0.051481 & 0.8232 \\
\hline
\end{tabular}

Source: Author's calculation

The findings in Table 5 indicate that the unemployment model has no serial correlation because the probability value is greater than 0.05 , no conditional heteroskedasticity because the probability value is also higher than $0.05 \%$, and there is a normal distribution.

\section{Conclusion}

This study used time series techniques to give an analytical summary of the connection between GDP and unemployment in Liberia from 2001 to 2019. Furthermore, the study provided an estimate of Okun's coefficient. Okun's coefficients are lower in industrialized nations with less controlled labor markets, according to Neely (2010). Unemployment is more sensitive to fluctuations in production since it is simpler to lay off employees. The Okun's coefficient may vary over time since the connection between unemployment and production growth is influenced by legislation, technology, tastes, social norms, and demographics. For the connection between unemployment rate and economic development, we used the unit root test, Dickey-Fuller test, bound cointegration test, and residual diagnostic test.

The results of this study showed that the data series was stationary in terms of unit root variations at first difference. Co-integration studies revealed that there is no co-integration link between unemployment and economic growth in Liberia in the short and long terms. Despite good growth rates at times, the Liberian economy has been unable to significantly reduce the unemployment rate. The main reason for this is that the Liberian economy is built on capital intensity rather than labor intensity.

As a result, it makes minimal contribution to the lowering of unemployment rates. Increasing the labor-force participation rate requires policies that promote labor-intensive activities and industries such as services, manufacturing, and agriculture. It should be noted that the report contains flaws and drawbacks, the first of 
which is the limited number of findings due to a lack of data on an annual basis, the second of which is that the time of civil crisis is not taken into account, and the third of which is that the analysis does not quantify the impact of labor market regulations.

However, since this is the first effort to empirically examine the causal relationship between these two variables using multiple regression models, the results of this study have particularly important policy implications for Liberian economic officials

\section{Recommendations}

In Liberia, attaining rapid development and providing high-quality employment continues to be a challenge. Economic development is essential for reducing unemployment rates. However, in order to achieve amazing growth rates that benefit the nation or economy, boost labor demand, and create respectable jobs, policymakers must establish policies that promote and sustain fast and sustainable economic development.

To decrease unemployment, the study suggests that the Liberian government focus its investments toward activities that expressly or implicitly promote job development, such as improving healthcare services, infrastructure building methods, education, and job-creating enterprises.

Strengthening crime prevention efforts would help Liberia establish a good image as a safe investment location for many investors (local and international), reducing unemployment rates.

\section{References}

Ume K. Chinwe K. Ann A. and Ukpere O., December 2020, "Economic growth and unemployment linkage in a developing economy: a gender and age classification perspective, Problems and Perspectives in Management, pp. $527-738$.

Sahnoun M. and Abdennadher C., 2019, "Causality between Inflation, Economic Growth and Unemployment in North African Countries”, Economic Alternatives, Issue 1, pp. 77-92

Babatunde A. and Victor A., 2020, "Economic Growth and Unemployment Nexus: Okun's Two-Version Case for Nigeria, South Africa and United States of America", Journal of Economics and Behavioral Studies (ISSN: 2220-6140), Vol. 12, No. 1, pp. 55-65.

Pasara M. And Garidzirai R., 2020, "Causality Effects among Gross Capital Formation, Unemployment and Economic Growth in South Africa”, economies, pp. 2-12.

Banda H. 2016. "The impact of economic growth on unemployment in South Africa: 1994- 2012”, Investment Management and Financial Innovations, 13(2), 246- 255.

Kreishan F., 2011, "Economic Growth and Unemployment: An Empirical Analysis” Journal of Social Sciences, pp. 228-331.

Moosa, I., 2008. Economic growth and unemployment in Arab countries: Is Okun's law Valid? Proceedings of the International Conference on the Unemployment Crisis in the Arab Countries. Mar. 17-18, Cairo- Egypt, pp. 1-19.

Chanshuai L. and Zi-juan L. (2012), “The relationship among Chinese Unemployment rate, economic growth and inflation", The AAEF Journal of Economics 1(1), 1-3.

Alhdiy F. 2015 "Short and Long-term Relationship between Economic Growth and Unemployment in Egypt: An Empirical Analysis”, Mediterranean Journal of Social Sciences, pp.: 454-462.

Sadikua M., Ibraimib A., and Sadikuc L., "Econometric Estimation of the Relationship between Unemployment Rate and Economic Growth of FYR of Macedonia", Procedia Economics and Finance 19 (2015) $69-81$.

Njoku A. and Ihugba O., November 2011 "Unemployment and Nigerian Economic Growth (1985-2009)", Mediterranean Journal of Social Sciences, pp. 23-32.

Akeju K. and Olanipekun D., November 2014 "Unemployment and Economic Growth in Nigeria", journal of Economics and Sustainable Development, pp. 138-144.

https://www.macrotrends.net/countries/LBR/liberia/unemployment-rate'>Liberia Unemployment Rate 19912021 
Journal of Economics and Sustainable Development

Vol.12, No.14, 2021

Appendix
\begin{tabular}{|l|l|l|}
\hline Time/ Year & $\begin{array}{l}\text { Unemployment, total } \\
\text { (modeled ILO estimate) }\end{array}$ & \multicolumn{2}{l|}{ of total labor force) } & GDP growth (annual \%) \\
\hline Units & $\%$ & $\%$ \\
\hline 2001 & 2.31 & 2.92 \\
\hline 2002 & 2.33 & 3.76 \\
\hline 2003 & 2.33 & -30.15 \\
\hline 2004 & 2.30 & 2.62 \\
\hline 2005 & 2.27 & 5.28 \\
\hline 2006 & 2.19 & 8.04 \\
\hline 2007 & 2.13 & 9.54 \\
\hline 2008 & 2.11 & 7.15 \\
\hline 2009 & 2.24 & 5.30 \\
\hline 2010 & 2.27 & 6.10 \\
\hline 2011 & 2.24 & 8.20 \\
\hline 2012 & 2.21 & 7.99 \\
\hline 2013 & 2.19 & 8.70 \\
\hline 2014 & 2.13 & 0.70 \\
\hline 2015 & 2.08 & 0.00 \\
\hline 2016 & 3.08 & -1.60 \\
\hline 2017 & 3.00 & 2.47 \\
\hline 2018 & 2.94 & 1.22 \\
\hline 2019 & 2.89 & -2.28 \\
\hline Average & 2.38 & 2.42 \\
\hline Cours: & & \\
\hline
\end{tabular}

Course: World Development Indicators (World Bank) 